\title{
GOOD GOVERNANCE IN THE POST-SOVIET SPACE. THE CASE OF ROMANIA AND THE EASTERN NEIGHBOURHOOD OF THE EUROPEAN UNION
}

\author{
Butnariu (Badea) Larisa-Florentin \\ Phd student, Department of Administrative Sciences, National School of Political and Administrative \\ Studies SNSPA, Romania \\ DOI: 10.46609/IJSSER.2021.v06i07.008 URL: https://doi.org/10.46609/IJSSER.2021.v06i07.008
}

\begin{abstract}
After the fall of the communist regime, the post-Soviet states have focused on modeling their systems of government according to European standards in order to transform into european administrations. The central concept of this approach is the good governance, which aims to ensure high quality public services, the development of civil servants and compliance with the european principles of transparency, participation, openness, efficiency and effectiveness (base of the European Administrative Space). Thus, the implementation of good governance in the post-Soviet space (Romania and the states in the eastern neighborhood of the European Union: Armenia, Azerbaijan, Belarus, Georgia, the Republic of Moldova and Ukraine) can be achieved with the help of the Center of Expertise for Good Governance and by applying the provisions of the European Code of Good Administrative Behavior under the supervision of the Ombudsmantype institutions.
\end{abstract}

Key words: good governance, ombudsman, principles, public administration, reform

\section{Introduction}

Ever since its consolidationby adopting the Maastricht Treaty in 1992, the European Union focused on creating a european governance model based on the adoption of the european values, such as, equality, freedom and democracy and respecting the european norms in the basic areas of public space (politics, economics and public administration).

Therefore, the concept of good governance was born after the end of the Cold War, when the former Soviet states detached themselves from communist model of government and embraced the european governance by applying democratic reforms and adopting European standards and principles. 
International Journal of Social Science and Economic Research

ISSN: 2455-8834

Volume:06, Issue:07 "July 2021"

\section{Good governance: definition and principles}

The concept of good governance was developed by the main global actors responsible for the socio-economical development of the states, such as the World Bank, the Organization for Economic Co-operation and Development (OECD) and the United Nations Development Program (UNDP), in order to limit the "bad governance" of post-communist states and establish an european model of good governance.(Tanja A. Borzel, Yasemin Pamuk, Andreas Stahn, 2008)

However, we need to focus in the first place on the concept of european governance, the main element of EU's policy making process. Therefore, european governance encompasses the activities of the European institutions and non-governmental organizationsin accordance with the objectives and norms of the European Union. (Ioan Alexandru, Mihaela Cărăușan, Sorin Bucur, 2005)

Thus, by establishing a governance structure, the Union has sought to outline the main features that member states and future candidates must internalize in order to become a part of the european space.

In order to shape good governance, the main economic actors of the European Union developed distinct definitions. Firstly, the World Bank defines good governance as "the use of political authority and exercise of control in a society in relation to the management of its resources for social and economic development." Secondly, OECD regards good governance "the rule of law, efficient public sector management, controlling corruption and reducing excessive military expenditures". Last but not least, UNDP characterizes good governance as "the exercise of economic, political and administrative authority to manage a country's affairs at all levels" or "the mechanisms, processes and institutions through which citizens and groups articulate their interests, exercise their political rights, meet their obligations and mediate their differences" (Tanja A. Borzel, Yasemin Pamuk, Andreas Stahn, 2008)

In short, through good governance, the European Union establishes a set of good practices in the fields of public space (economy, politics and public administration) to be applied by the Member States' management in order to effectively and efficiently manage state resources (human, financial and logistics) in the elaboration and implementation of public policies.

\subsection{The principles of good governance}

According to UNDP, the main areas of application of good governance are:" $₫$ legislature, judiciary, and electoral bodies; public and private sector management; decentralisation and 
International Journal of Social Science and Economic Research

ISSN: 2455-8834

Volume:06, Issue:07 "July 2021"

local governance; civil society organisation and governance."(Tanja A. Borzel, Yasemin Pamuk, Andreas Stahn, 2008)

Consequently, good governance is ensured by public authorities in order to establish a legal framework for public policy-making that takes into account the needs and preferences of citizens and guarantees the respect of fundamental human rights and freedoms by applying the following principles:

- „Openness (legitimacy of European actions within the Member States);

- Participation (the relationship between the involvement of European citizens in the decision-making process and their degree of trust in european policies);

- Accountability (clarification of the roles of the Community institutions and the Member States in the decision-making process);

- Effectiveness (setting clear objectives and assessing the impact of European policies);

- Coherence (involvement of local authorities in European policy-making). (Ioan Alexandru, Mihaela Cărăușan, Sorin Bucur, 2005)

Indeed, in order to establish the progress made by the european states in improving governance at the national level, the World Bank established in $1997 \mathrm{a}$ few indicators to assess the adoption and application of European governance, such as:

- "Responsibility (respect of fundamental human rights and freedoms);

- Political instability and violence (frequency of government threats and changes);

- The effectiveness of the Government (the ratio between the competences of the administrative apparatus and the quality of the provision of public services);

- The quality of regulation (the incidence of policies that the market does not agree with);

- The rule of law (the quality of the application of the norms and the observance of the laws and court decisions, but also of the perspectives of manifestation of the crimes) and

- The control of corruption (exercising public office for personal gain)." (Ioan Alexandru, Mihaela Cărăușan, Sorin Bucur, 2005)

As a result, based on these indicators we can follow the degree of democratic reform of the postSoviet states in the eastern neighborhood of the European Union: Moldova, Ukraine, Belarus, Georgia, Armenia and Azerbaijan on respect of fundamental human rights and freedoms, the rule of law, ensuring free and fair elections and reducing the degree of corruption (requirements of European governance that must be respected in order to be a part of the European Administrative Space - EAS).

\section{The tools of good European governance}


International Journal of Social Science and Economic Research

ISSN: 2455-8834

Volume:06, Issue:07 "July 2021"

Following the declaration of good European governance as one of the European Commission's strategic objectives in 2000, the European Union has created a number of instruments for its implementation in the Member States. A good example is the creation of the White Paper on European Governance in 2001 to ensure the strengthening of democratic legitimacy by implementing the principle of participation, through which civil society "gets a voice" in the decision-making process and can draw attention to their needs. (Tanja A. Borzel, Yasemin Pamuk, Andreas Stahn, 2008)

As a matter of fact, to ensure the application of good governance at the level of European states (both at national and local level), the Center of Expertise for Good Governance was created to promote european standards and the exchange of good practices. The Center provides capacitybuilding programs and political and legal advice to local, regional and national authorities to support ongoing public administration processes and local government reform ailored to the specific needs of countries. (Center of Expertise for Good Governance)

Thus, a series of tools have been developed to assist local and central state authorities in the application of good governance, such as the European Label of Excellence in Governance (ELoGE) - awarded to local authorities that have reached a general level of good governance by respecting the principles and providing high quality public services to citizens. (12 principles)

Another key instrument of European governance is the Strategy for Innovation and Good Governance at Local Level, approved by a decision of the Committee of Ministers of the Council of Europe in 2008, which includes the $\mathbf{1 2}$ principles of good governance:

- "Principle 1. Fair conduct of elections, representation and participation $\rightarrow$ local elections are conducted freely and fairly in accordance with international standards and national law. Moreover, the participation of all citizens in the decision-making process at local level (women and men) is guaranteed, the decisions being taken according to the will and interests of the citizens;

- Principle 2. Sensitivity $\rightarrow$ Government objectives, structures and procedures are adapted to the expectations and needs of citizens, the provision of public services is ensured to everyone and their requests and complaints are resolved within a reasonable time;

- Principle 3. Efficiency and effectiveness $\rightarrow$ The efficient use of all available resources to assure a performance management system to improve the efficiency and effectiveness of public services;

- Principle 4. Openness and transparency $\rightarrow$ Decisions are taken and implemented in accordance with the law and public information (except the classified ones) is available to all citizens; 


\section{International Journal of Social Science and Economic Research}

ISSN: $2455-8834$

Volume:06, Issue:07 "July 2021"

- Principle 5. Rule of law $\rightarrow$ The observance of the law and judicial decisions by local authorities, the adoption of rules and regulations in accordance with the law and their impartial application;

- Principle 6. Ethical behavior $\rightarrow$ Implementation of measures to prevent and combat all forms of corruption and resolve conflicts of interest between various public institutions;

- Principle 7. Competence and capacity $\rightarrow$ Professional development of civil servants;

- Principle 8. Innovation and openness to change $\rightarrow$ Modernizing the provision of civil services;

- Principle 9. Sustainability and long-term guidance $\rightarrow$ Governmental decisions must be oriented to the needs of the local community, internalize all costs and not transfer economical, environmental and social problems and tensions to future generations;

- Principle 10. Sound financial management $\rightarrow$ Preparing the multiannual budget by consulting the citizens and including taxes, revenues and loan management and dividing it fairly;

- Principle 11. Human rights, cultural diversity and social cohesion $\rightarrow$ Respect of human rights, cultural diversity by local authorities, combating discrimination and promoting social cohesion (access to essential public services is guaranteed to disadvantaged people) and

- Principle 12. Responsibility $\rightarrow$ All decision makers are responsibile for their decisions and can be reported and sanctioned in order to repair the faulty local administration case." (12 principles)

\section{Good governance - basis of the European Administrative Space}

Good governance plays an important role in the process of adherence to the European Administrative Space of the post-Soviet states in the eastern neighborhood of the European Union (Armenia, Azerbaijan, Belarus, Georgia, the Republic of Moldova and Ukraine) because it traces the best governance practices applied within the developed states of the European Union. Therefore, these states need to reform by applying the european administrative standards and principles.

In other words, the application of the concept of good governance at national level results in the efficiency of its public administration by respecting the european administrative principles (accountability, openness, transparency, efficiency and effectiveness).

Thus, in order to strengthen the administrative capacity of a state, the European Commission identified a number of factors of public administration reform, based on good governance, such as: 
- "The process of cultural and organizational change;

- Involvement of civil society;

- Using a clear methodological and technical approach;

- Political commitment;

- Clear definition of responsibilities;

- Exchange of good practices at EU level;

- Monitoring and evaluation techniques;

- Continuity and stability of reforms". (Promoting good governance, 2014)

In this regard, the administrative reform of these states is made by applying the principlesof excellencelisted in Figure 1.

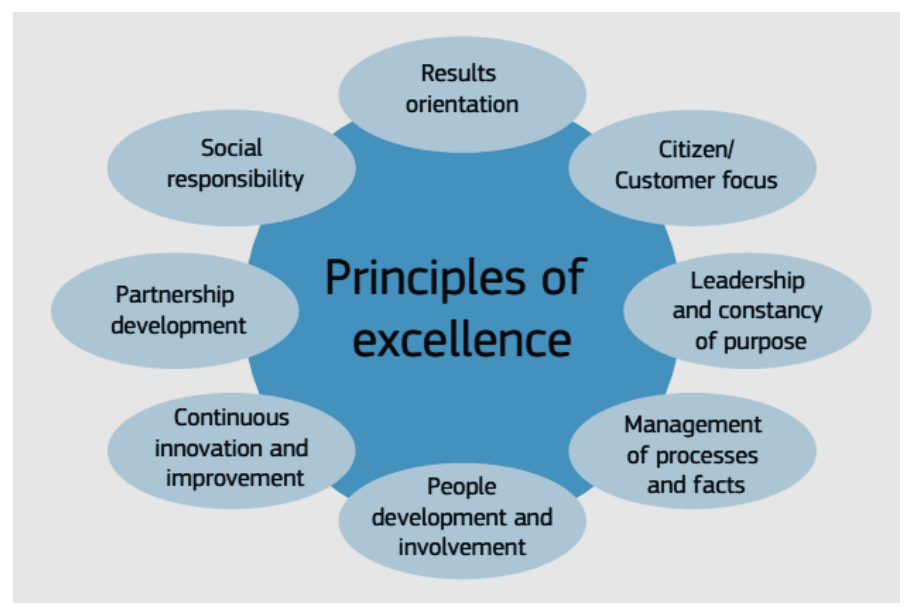

Figure 1.Principles of excellence Principiile excelenței (Source: Promoting good governance, p.9)

In other words, the administrative reform based the principles of excellence listed above focuses on: • analyzing the problems that needs to be solved through reforms, •implementing a quality management system of public services provided to citizens, •reducing bureaucracy and simplification of administrative procedures, •modernization of human resources management, -ensuring the development of skills of civil servants at all levels (from management to beginner) and $\bullet$ implementing a system for monitoring and evaluating the quality of public services. (Promoting good governance, 2014)

\subsection{Good governance in the eastern neighbourhood of the European Union}




\section{International Journal of Social Science and Economic Research}

ISSN: $2455-8834$

Volume:06, Issue:07 "July 2021"

In this section, I will focus on the current situation of the application of good governance at the level of national public administrations undertaken by the post-Soviet states (Romania and the states in the eastern neighborhood of the European Union).

Firstly, within the Republic of Armenia we can observe the implementation in 2019 of the governance project on democratic state consolidation by developing efficient, accountable and transparent governmental bodies, promoting the principles of good governance and promoting citizen participation and equal opportunities for women in decision-making. In addition, the Armenian state has launched a series of workshops based on civil society participation in decision-making, performance management and inter-municipal cooperation. Moreover, the Center of Expertise for Good Governance offered the necessary financial support for the development of the community facilities of the 52 municipalities by broadcasting live council sessions and providing grants for launching inter-municipal cooperation initiatives and usage of the e-learning tool in 2020. (Annual activity report, 2019)

Secondly, in the Republic of Moldova the Institute for Development and Social Initiatives (IDIŞ) "Viitorul", with the support of the Center for Expertise for good governance implemented the Good Practices Program (BPP) in 2019 for identifying, promoting and disseminating good practices among local public authorities. This program focuses on the application of the principle of transparency in public space, the involvement of local authorities in urban revitalization and the protection of authentic cultural heritage and traditions and the development of smart communities by providing efficient public services to all citizens. (Annual activity report, 2019)

Thirdly, regarding Romania, the Center of Expertise for Good Governance collaborated with the Romanian Institute of National Administration (INA) for the preparation and implementation of the Leadership Academy Program (LAP) in 2018, and in 2020 will organize a workshop for the development of municipalities in European standards. (Annual activity report, 2019)

Fourthly, the Republic of Ukraine implemented the Program "Decentralization and reform of local government in Ukraine" (March 2018 - June 2020), through which the Local Government Association "Agglomeration of Kiev" was established in order to improve international cooperation within the metropolitan area of Kiev and established a national training framework for local civil servants. In addition, it was emphasised the need of setting up a network of regional trainers, a web platform on human resource management and the organization of leadership academies for specific groups by local authorities. Moreover, in 2019 the Center of Expertise for Good Governance supported the Ministry of Community and Territorial Development of Ukraine to set up the Bureau to Support Decentralization Reform and ensure that the legal expertise provided by the office according the European Charter of Local SelfGovernment.(Annual activity report, 2019) 
Last but not least, in the case of the Republic of Belarus, the Center of Expertise collaborated with the Academy of Public Administration and the Minsk Regional Executive Committee to develop a methodology for developing public sector job profiles. In addition, in 2019 a seminar was organized by the National Center for Legislation and Legal Research in Belarus to improve public participation in the legislative process, and between 22-23 October 2019 a conference on modernization and reform of the civil service was organized by Minsk Academy of Public Administration. (Annual activity report, 2019)

As we can see, the Center of Expertise for Good Governance (except the Republic of Azerbaijan) plays an important role in the development of the national public administration of post-Soviet states in the eastern neighbourhood of the EU and contributes to establishing a model of good governance. In other words, the reforms based on the principles of good governance represent essential steps in joining the European Administrative Space and transnforming their administrative systems into european administration (without joining the European Union).

\section{European Code of Good Administrative Behavior - the activity of the ombudsman in the eastern neighborhood of the European Union}

In addition, another instrument for ensuring good governance at the level of state public administration is the European Code of Good Administrative Behavior, which sets out the ethical principles of administration and good administrative practices.

Thus, the European Code of Good Administrative Behavior is both an information tool on the professional conduct of civil servants and a mean of creating a climate of trust and mutual respect between citizens and civil servants, on the one hand, and between citizens and public administration authorities, on the other hand. (Grigore Alexandru Jianu, 2013)

Therefore, Articles 4-12 contain the basic principles that civil servants must apply and respect, namely:

- "Legality (the official will act in accordance with the law and the rules and procedures of the EU);

- Non-discrimination (equal treatment in processing public requests and making decisions);

- Proportionality (decision-making by respecting the right balance between the interests of individuals and the interest of the general public, without limiting the rights of citizens);

- Lack of abuse of power (the official will not exercise his power for purposes that have no legal basis or are not justified by any public interest); 


\section{International Journal of Social Science and Economic Research}

ISSN: $2455-8834$

Volume:06, Issue:07 "July 2021"

- Impartiality and independence (the official will not act on the basis of personal, family, national interests and political pressure and will not offer preferential treatment to anyone);

- Objectivity (making decisions by taking into account relevant factors);

- Legitimate expectations, consistency and approval (the official will be consistent in his work, apply the rules of the institution and respect the legitimate and reasonable expectations of the public according to the way the institution has acted in the past);

- Correctness (the official will act in an impartial, fair and reasonable manner);

- Kindness (the official will be dedicated to his duties, correct, kind and accessible in relations with the public)." (The European Code of Good Administrative Behaviour)

Thus, all states aim becoming an european administration (both the Member States of the Union and those seeking to join the European Administrative Area - the Eastern Neighborhood States) must apply the provisions of the European Code of Administrative Conduct in all administrative institutions.

Therefore, the European Union through the Treaty on the Functioning of the European Union developed an institution to link the citizens and public institutions, namely the Ombudsman. Thus, according to the Article 228 of the treaty 'The European Ombudsman shall be empowered to receive complaints from any citizen of the Union or any natural or legal person residing or maladministration in the work of the institutions, bodies, offices or agencies of the Union, with the exception of the Court of Justice of the European Union." (The Ombudsman)

The European Ombudsman is elected by the European Parliament for a 5-year term, which may be renewed, exercising his functions independently without seeking or accepting instructions from the Government and other public institutions. He can be dismissed by the Court of Justice on a complaint from the European Parliament if he no longer fulfills the conditions required for the performance of his duties or has committed a serious misconduct. (The ombudsman)

Therefore, in order to ensure the proper functioning of the public administration of each european state, the European Network of Ombudsmen was set up in 1996 as a mechanism for cooperation and resolution of maladministration at EU level, comprising both national ombudsmen as well as similar bodies (90 offices in 32 European countries). (Grigore Alexandru Jianu, 2013)

As a result, each european state has an ombudsman (also called the human rights commissioner, public defender, etc.) who oversees the application and observance of public administration principles and the degree of trust and respect between citizens and civil servants of state administrative authorities. 
International Journal of Social Science and Economic Research

ISSN: 2455-8834

Volume:06, Issue:07 "July 2021"

The ombudsman-type institution of the Romanian state, the People's Advocate, was created in 1991 for a 5-year term in order to defend human rights and fundamental freedoms in their relations with public authorities, answering to Parliament. The People's Advocate receives, examines and resolves, in accordance with the law, the petitions addressed by any citizen(sent by mail, telephone, fax, or directly through hearings), regardless of citizenship, age, sex, political affiliation or religious beliefs, the petitioner having to prove the refusal of legally resolving his request. (Avocatul poporului)

In order to resolve the citizens 'requests, the People's Advocate requests the public administration authority in question to take the appropriate measures to defend the rights and freedoms of individuals and notifies the hierarchically superior authorities on violating citizens' rights to provide public services and implement necessary measures. In this regard, the People's Advocate has the right to make his own inquiries, to ask the public administration authorities for information or documents necessary for the investigation, to hear and take statements from the heads of public administration authorities and from any official who can give the necessary information to resolve the petition. (Avocatul poprului)

Due to the fact that the European Administrative Space to the East is possible through the adoption and respect of the principles of public administration and good governance, the Ombudsman plays an important role in monitoring and reporting the bad administartion cases and improving their administrative systems.

Next, I will analyze the activity of ombudsman-type institutions in the Eastern Neighborhood states of the European Union.

The Office of the People's Advocate of Moldova (former Center for Human Rights of Moldova) was created through the Law on the People's Advocate no. 52 of 03.04 .2014 as an independent public authority to ensure the guarantee of respect for fundamental human rights and freedoms by central and local public authorities, institutions, organizations and enterprises and persons with positions of responsibility. It comprises 4 parliamentary ombudsmen (one specialized in child protection issues - Child Advocate), officials assisting the work of ombudsmen and four representations located in: Bălţi, Cahul, Comrat (Autonomous Territorial Unit "Gagauz-Yeri") and Varniţa. (Moldovan ombudsman)

In order to notify the institution, the moldovan citizens must comply with the following conditions:

- „the submission of the application until the expiration of one year from the day of the violation of the petitioner's rights or freedoms or from the day when he found out about the alleged violation; 


\section{International Journal of Social Science and Economic Research}

ISSN: $2455-8834$

Volume:06, Issue:07 "July 2021"

- mentioning the name, surname, domicile of the petitioner, brief description of the circumstances of the complaint and the name of the authority / person in charge if this person is known;

- if the facts relied on in the application have been examined by other authorities, the copies of the replies of those authorities shall be annexed. " (Moldovan ombudsman procedure)

The Commissioner for Human Rights of the Ukrainian Parliament oversees the observance of fundamental human rights and freedoms, assisted by a Secretariat working on a variety of issues, such as: social, economic and humanitarian rights, children's rights, non-discrimination and gender equality, access public information, protection of personal data, the rights of internally displaced persons or the rights of military personnel. (Ennhri Ukraine)

In fact, the current Ombudsman's mandate expired in April 2017 and Parliament did not vote for any of the three candidates within the required timeframe. However, on August 21, 2017, a bill was submitted to Parliament on the issue of appointing the ombudsman by three members of the Petro Poroshenko bloc and a deputy of the Vidrodzhennia parliamentary group, suggesting the use of the secret ballot, approved on October 26 by the Scientific Department of Experts. (Ukraine ombudsman)

As a result, the inability to elect an ombudsman generated by the disorderly voting procedure indicates a defect in the conduct of the state's administrative process by the slowdown in decision-making and the lack of a representative of the citizens to ensure good administration.

The Public Defender of Georgia was appointed in 2014 as the structure for ensuring the implementation, promotion and protection of the Convention on the Rights of Persons with Disabilities, being designated under the Law on the Elimination of All Forms of Discrimination as a body for monitoring law enforcement and examining violations of human rights independently. (Ennhri Georgia)

According to the 1996 Organic Law on the Public Defender of Georgia, the functions and duties of The Public Defender consist in:

- "providing counseling and effective monitoring of respect of human rights;

- $\quad$ supporting the authorities in fulfilling their human rights commitments;

- providing human rights educational activities of the highest professional and academic quality and enhancing the Ombudsman's role as a primary institution in teaching and researching human rights ". (Ennhri Georgia) 
International Journal of Social Science and Economic Research

ISSN: 2455-8834

Volume:06, Issue:07 "July 2021"

The Armenian Human Rights Commission was established by Decree NH-32 of the President of the RA on 27 April 1998 as an advisory body whose main tasks were to support and protect human rights and freedoms, analysis of draft legal acts submitted to the President on human rights and human constitutional freedoms, giving an opinion on laws submitted for signature and decisions of the Government, discussing complaints on human rights violations and preparing the annual report on safeguards and protection of human rights, etc. (Armenian ombudsman)

The Ombudsman Institute was established on 28 December 2001 on the basis of the Constitutional Law on the Commissioner for Human Rights (Ombudsman) of the Republic of Azerbaijan, whose mission is to restore human rights and freedoms violated by governmental or local bodies and officials of the Republic of Azerbaijan and to prevent human rights violations in the cases provided for by the Constitutional Law (Ennhri Azerbaijan)

Unfortunately, the Republic of Belarus is the only Eastern European state analyzed in my research that does not currently have an ombudsman. However, there was the creation of such an institution in 1996 with the drafting of the Law on the Commissioner for Human Rights in the Republic of Belarus. (Belarus ombudsman)

\section{Conclusion}

In conclusion, good governance is an important step in reforming and shaping the public administrations of the post-Soviet states (Romania and the states in the eastern neighborhood of the European Union: Armenia, Azerbaijan, Belarus, Georgia, Moldova and Ukraine) as european administrations by adopting and implementing the principles of good governance.

Thus, the integration of these principles in the national administrative system contributes to ensuring the provision of high quality public services to all citizens (regardless of gender, ethnicity, religion) and strengthening of the relationship of trust and responsibility between public institutions and also between citizens and public authorities.

Moreover, in order to transform into european administrations, the eastern states need also to apply the provisions of the European Code of Good Administrative Behavior these states to ensure a good administration in all public services fields (political, economical, social and public administration- local, regional and national).

Furthermore, the activity of ombudsman institutions in reporting violations by public authorities and infringing on the rights and freedoms of citizens in accessing public information and providing the necessary services contributes to a better public administration. 


\section{International Journal of Social Science and Economic Research}

ISSN: $2455-8834$

Volume:06, Issue:07 "July 2021"

Last but not least, another step of improving public administration of these states consists in the assistance offered by the Center of Expertise for Good Governance by adopting measures, such as: ensuring the participation of civil society in decision-making, the principle of transparency, the development of communities and municipalities to European standards and the training and professional development of civil servants (regardless of their degree).

In conclusion, the application of the concept of good governance to the national administrative systems of post-Soviet states consists a necessary step in their transformation into european administration and joining the European Administrative Space.

\section{References}

[1] Tanja A. Borzel, Yasemin Pamuk, Andreas Stahn,Good governance in the European Union, Berlin Working Paper on European Integration No. 7,January 2008, pp.11-21

[2] Ioan Alexandru, Mihaela Cărăușan, Sorin Bucur, Drept administrativ, Editura Lumina Lex, București, 2005, pp.54-55

[3] Center of Expertise for Good Governance.Retrieved from https://www.coe.int/en/web/good-governance/centre-of-expertise

[4] 12 principles. Retrieved form https://www.coe.int/en/web/good-governance/12-principles

[5] Promoting good governance, European Social Fund thematic paper, European Commission, Directorate-General for Employment, Social Affairs and Inclusion, Unit E1, Luxembourg: Publications Office of the European Union, January 2014, pp.6-10

[6] Annual activity report, Centre of Expertise for Good Governance, The Council of Europe Secretariat, 2019, pp.6-21

[7] Grigore Alexandru Jianu, Instituția Ombudsmanului la nivel european, Editura I.R.D.O, București, 2013, pp.27-33

[8] The European Code of Good Administrative Behaviour. Retrieved form https://www.ombudsman.europa.eu/ro/publication/en/3510

[9] The ombudsman. Retrieved from https://www.ombudsman.europa.eu/ro/legal-basis/treaties/ro

[10] Avocatul poporului. Retrieved form https://avp.ro/index.php/prezentare/avocatul-poporului-institutie-de-tip-ombudsman/ 
International Journal of Social Science and Economic Research

ISSN: 2455-8834

Volume:06, Issue:07 "July 2021"

[11] Moldovan ombudsman. Retrieved from

http://old.ombudsman.md/ro/content/scurt-istoric

[12] Moldovan ombudsman procedure. Retrieved from

http://old.ombudsman.md/sites/default/files/procedura.pdf

[13] Ennrhi Ukraine. Retrieved from http://ennhri.org/our-members/ukraine/

[14] Ukraine ombudmsan. Retrieved from https://democracy-reporting.org/ukraines-political-maneuvering-parliament-does-notappoint-an-ombudsman/

[15] Ennrhi Georgia. Retrieved from

http://ennhri.org/our-members/georgia/

[16] Armenian ombudsman. Retrieved from https://www.ombuds.am/en_us/site/AboutHistory

[17] Ennrhi Azerbaijan. Retrieved from http://ennhri.org/our-members/azerbaijan/

[18] Belarus ombudsman. Retrieved from https://humanrights-online.org/institute-of-theombudsman-in-the-republic-of-belarus-position-of-the-belarusian-section-of-the-ishr/ 